Employment of the Physically Handicapped and the ADA

\author{
Edward K. Marlow \\ Nancy D. Marlow \\ Eastern Illinois University \\ Charleston, Illinois
}

"I'm going to do whatever it takes to make sure the disabled are included in the mainstream...they're not going to be left out anymore." [George Bush endorsing the Americans with Disabilities Act of 1989 (S. 933)]

"They never even gave me a chance." [Michele Marlow, a seventeen year-old girl in a wheelchair, denied employment by Hardee's because "the company manual says that employees must be on their feet while they are working."]

\title{
Introduction
}

Many businesses are experiencing difficulty finding qualified employees, and this situation is expected to get worse. A recent article in the Wall Street Journal indicated that almost 80 percent of the business firms surveyed expected a shortage of skilled labor in the next decade [2]. This predicted labor shortage is expected to force companies to recruit more aggressively and to look at sources they may not have considered seriously before.

A 1988 survey revealed that two-thirds of Americans with disabilities between the ages of 16 and 64 are unemployed [13]. In the past businesses ignored the physically handicapped in most employment situations. The emphasis in Equal Employment Opportunity (EEO) and Affirmative Action (AA) programs was on other groups of people. However, AA programs are now being required to correct past discrimination against this large segment of the population. The Americans with Disabilities Act (ADA) will focus employers' attention on hiring the physically handicapped.

\section{Definition of Handicapped}

Under the Rehabilitation Act of 1973, handicapped conditions included:

Conditions where the disability requires multiple services over an extended period of time and results from amputation, blindness, cancer, cerebral palsy, cystic fibrosis, deafness, heart disease, hemiplegia, mental retardation, mental illness, multiple sclerosis, muscular dystrophy, neurological disorders (including strokes and epilepsy), paraplegia, quadriplegia, and other spinal cord conditions, renal failure, respiratory or pulmonary dysfunction and other disability specified by the Secretary in regulations he shall prescribe. [p. 753]

The Department of Labor has further defined a handicapped individual as "any person who has a physical or mental impairment which substantially limits one 
or more of the person's major life activities." However, the handicapped individual must be recorded as having the impaired condition. Life activities are any activity such as employment, education, communication, walking, or caring for one's self. This clearly means any handicapped individual who has difficulties in obtaining a job or advancing a career.

Rather than develop a new definition for the term "qualified individual with a disability," the ADA includes a comparable definition to the one above. The term applies to people with a record of such an impairment, such as someone recovered from cancer, as well as people "regarded" as having a disability, such as a person with a disfiguring injury. It would add AIDS victims and recovering drug and alcohol abusers to the list of those eligible for legal protection.

\section{Developments up to the ADA}

Over forty years ago, the Department of Labor conducted a study and found that there were no "significant differences in productivity, injuries on the job, absenteeism, or voluntary resignation between disabled and non-disabled workers." [217] Current research indicates the same results as found in 1948. The question wtill remains, why do the handicapped still have so many problems obtaining employment? Over eight million disabled Americans who wanted to work were unemployed in 1986, and half had household incomes of $\$ 15,000$ or less. Transfer payments to the disabled are reaching nearly $\$ 60$ billion a year.

To date, the major piece of legislation affecting the handicapped has been the Rehabilitation Act of 1973, Sections 503 and 504. Section 503 states that "any employer entering into a government contract or subcontract with a value in excess of $\$ 2,500$ must pursue a policy of non-discrimination against the handicapped." Businesses with federal contracts in excess of $\$ 50,000$ and 50 or more employees are required to prepare affirmative action plans [23].

Section 504 prohibits discrimination of the handicapped in any program receiving federal financial aid-this applies to government agencies, hospitals, schools, social services, businesses, any program or activity conducted by an Executive agency, and by the U. S. Postal Service [12]. The only contracts that are exempt from this clause are insurance contracts, procurement contracts, or guaranty contracts.

Sections 503 and 504 protect individuals from employers who do not provide "reasonable accommodation" to their employees. Any act performed by a business to help a handicapped individual perform his job is a form of "reasonable accommodation." Reasonable accommodation includes physical or architectural changes of the building or work area, or changing the work hours or schedules, or slightly modifying the job responsibilities [7]. Unfortunately there is no standard definition of "reasonable accommodation" and most working definitions have been decided in the courts on a individual case basis.

It is the responsibility of the employer to prove that hiring handicapped individuals will put an "undue hardship" on his business. The other alternative for a company in a discrimination case is to prove that it has done everything "rea- 
sonable" to advance and employ handicapped individuals. Only if an individual cannot meet or produce at the company's standards can a company refuse to hire or dismiss a handicapped individual. (This would apply only after any reasonable accommodations have been made).

The ADA will drastically change the way business views hiring the handicapped. This will be the most sweeping civil rights bill in more than 25 years, perhaps the most sweeping ever. Estimates are that 43 million people in the U.S. have some disability. Ironically, this new legislation will enhance the employment capabilities of the disabled at the very time the employment potential of other minorities is being diminished by recent Supreme Court rulings.

\section{Americans With Disabilities Act}

In May, the House overwhelmingly passed the ADA; the Senate had already approved the bill. After a joint conference to resolve the differences, President Bush has indicated that he will sign the bill into law. The ADA will guarantee the nation's 43 million deaf, blind, lame, and otherwise infirm people against job discrimination. The legislation would make employment discrimination against any qualified person with a disability forbidden. Employers must make facilities accessible to the person hired, and make the necessary adjustments for that person to work. Businesses and other employers with fewer than 15 employess are exempt (so far).

In Senate debate, proponents compared the ADA to the Civil Rights Act of 1964. Some turned the comparison back to the freeing of the slaves. The legislation borrows form the 1964 Civil Rights Act and sections of the Rehabilitation Act of 1973 dealing with companies, institutions, and groups that receive government money.

As mentioned earlier, rather than list specific disabilities-estimated to exceed 900- the law defines disability as "a physical or mental impairment that substantially limits one or more of the major life activities." Disabled individuals must be hired if they are qualified to do the "essential functions" of the job. Exceptions - surely food for numerous future legal tests—exist. The disabled need not be hired if it would pose "an undue hardship." Existing public accommodations must be made accessbile as long as the changes are "readily achievable" without creating an "undue financial burden." No one has given any guideline as to what these phrases really mean, although the terminology is the same as previous civil rights legislation.

The disabled are one of the newest of the "dispossessed minorities" to come to public attention. It has only been in recent years that society has started to address the problems and needs of disabled persons. Society has slowly recognized their fundamental right to live complete lives and receive simple respect. As laws, regulations, and programs are being enacted to deal with legal, institutional, and architectural barriers that the disabled must face, the basic prejudice against dis- 
abled person must be acknowledged. This prejudice, like all prejudice, stems from the thoughts and attitudes of individuals.

Most discrimination against the disabled occurs without animosity. It is based on assumptions about work and the people who have worked before; it is based on decisions about disability, not about individual disabled people. Unlike many prejudices, those against blacks or homosexuals, for example, the prejudice against the disabled does not stem from hatred or fear as much as it does from embarrassment or discomfort. Few people hate the disabled the way a racist hates blacks or a sexist hates women. Most people don't even think about the disabled at all unless they are nearby, and then they feel uncomfortable-for a variety of reasons.

Lew Hankins, the late director of United Cerebral Palsy, spent most of his life in a wheelchair and once commented how often he had people tell him how "amazing" he was. He noted that a disability is not something you sign up for to prove how "brave" you are. Rather, it's a fact of life, and you try to give it as little importance as possible.

A recent article on perceptions of the handicapped in the media pointed out that if disabled persons are not portrayed as helpless, they are seen as having super-human compensatory powers. Neither of these are accurate, nor are they fair. The disabled aren't "cripples" and they're not as a rule completely helpless, but they aren't necessarily noble either. They don't need constant compliments about how well they're "adjusting." While it is inspiring to see movies about onelegged men who walk across the country, it doesn't do most of the disabled any good to be compared to that kind of standard.

According to the Department of Education, as of July 1988, there were more than 55,000 disabled students who graduated from college last year. Twenty percent of these individuals graduated with business degrees, fifteen percent with computer degrees, and the rest with degrees in education, arts, languages, and science [29] Besides increased education, increased activism by the disabled was stated as a reason for more individuals with disabilities actively participating in the labor force. Because of increased education and activism, there are more handicapped applicants looking for corporate job. [3]

In a study conducted by the Personnel magazine, 95 percent of 300 responding human resources directors felt that the quality of work is the number one concern when hiring a physically or mentally handicapped individual. [9] Another survey found employers' concerns to be fear of rejection by co-workers, how the public will perceive the employer, how it will affect business, employee turnover, increased operating costs, cost of plant and equipment adoptions, training and safety accommodations, and cost of insurance. [4]

The United States Chamber of Commerce and National Association of Manufacturers found that 90 percent of the companies learned that hiring the handicapped had no effect on insurance costs [16]. Under current legislation, benefit packages must be equal for both handicapped and non-handicapped workers. The cost is determined individually be each insurance carrier. Peters found that 
handicapped workers have higher attendance and lower turnover rates than nonhandicapped workers, perhaps because the handicapped employee values her job more. In addition, handicapped workers weredescribed as hardworking, safe, and dependable. Also, handicapped workers were found to have a longer tenure than the non-handicapped. [23]

The ADA will force a tremendous change in the way American small business looks at the physically handicapped. Viewpoint may be one of the key issues affecting how well a company can adjust to the ADA. Companies that resist the intent of the law or wish to make only minimal commitment will encounter the same difficulties that companies have had with EEO/AA and OSHA legislation. Companies that take a more positive perspective will be more able to find and employ the physically. Fortunately, there are several agencies that can provide help for a small business seeking to employ the handicapped and several incentives to do so.

\section{Aids to Hiring the Handicapped}

\section{Financial Incentives}

The federal government provides a number of economic incentives for companies to hire the handicapped. In addition to purely humanistic concerns, the government benefits economically when the handicapped are hired since it reduces worker compensation and other government programs. Section 190 of the Tax Reform Act of 1986 allows companies to receive an annual tax credit up to $\$ 35,000$ for site improvements that make their organizations more accessible to individuals with disabilities.

The Targeted Jobs Tax Credit Program, created by the Internal Revenue Act of 1978 and the Work Incentive Program, applies to newly disabled workers who quaiify as a targeted class. In the first year a company can claim 50 percent of the first $\$ 6,000$ paid in wages as a tax credit. Twenty-five percent of the $\$ 6,000$ paid in the second year is deductible. The credit is limited to 90 percent of the company's tax liability. There is no limit to the number of employees that can be covered under this grant. If an employee moves from one company to another, the new employer is also entitled to this credit. The purpose of this tax credit is to help compensate for lost productivity during the emplyee's training period.

HIIRE (Help through Industry Retraining and Employment) will also pay for the cost of training handicapped workers. This program will reimburse half of the new worker's beginning hourly wage for up to six months.

\section{Program and Support Services}

There, are a number of additional programs and support services designed to help the handicapped individual enter and become estabished in the workforce. With technological aids and training, handicapped employees can be as productive as the non-handicapped. 
The Job Accomodation Network (JAN) is an agency that makes available to businesses a database of ways to accomodate handicapped workers. "It is a free computer database that provides employers with practical solutions of adapting jobs for disabled applicants and employees." [5, p.10] It includes information abour job modifications, technological devices, and various work place adoptions. JAN has set up a toll free number (1-800-JAN-PCEH) for easy access. This agency was started May, 1984 by the President's Committee on Employment of the Handicapped. This service is provided to any business, regardless of size, willing to share its information about the accommodation of the handicapped. The advantage of this database is that companies can have easy access to solutions to situations rather than allowing them to dismiss problems as being too costly or complex. Every company does not have to reinvent the wheel; this is an obvious advantage for small businesses.

A survey conducted by JAN found that 99.6 percent of the companies surveyed said thay would use JAN again. However, slightly over half of the companies were willing to provide follow-up information. Overwhelmingly, companies reported that they received their information promptly and that they had no trouble contacting JAN [22]. JAN receives over 150 calls a day with the vast majority of them coming from private companies and federal agencies. Its success rate is 73 percent and in 70 percent of the cases the expense of modification required was less than $\$ 100[1]$

\section{Employee Support Services}

There are a number of Employee Support Services available for the handicapped worker. These services are set up by rehabilitation agencies and businesses. In order for these services to be successful, all people in the company, especially top management, must be involved in them. While there are many types of support services, probably the most important one is the preparation of handicapped workers for the work place. These programs are developed around areas such as vocational training, work adjustment, job modification, or job placement services [10] A study conducted by Young, Rosati and Vandergoot [30] found that respondents perceived the rehabilitation services as a source for job applicants. Businesses contacted these services frequently to fill job openings in their organizations.

According to Stace [21] the group that would benefit most from vocational rehabilitation is young women with disabilities seeking to enter the work force. This protected class is less likely to have work experience or education qualifications. This group has the double disadvantage of being female and being handicapped.

Microcomputer Education for the Employment of the Disabled or MEED is a project set up by Miami University (Florida) that trains the handicapped on microcomputers and teaches specific knowledge needed to become a manager. This year-long program teaches microcomputer packages such as dBase III, Lotus 1, 2, 3 and Microsoft's Word. According to the chairman of MEED's Business Advi- 
sor Council, the businesses who employ MEED graduates are "able to get highly qualified, strongly motivated employees at the same time reducing training costs." [6, p. 78]. The students in this program receive software portfolios donated by Ashton-Tate and Microsoft. Also donated are free speech input devices which allow quadraplegics to give commands to the computer by voice.

The "Phoenix Corporation" is a project funded by thirty different companies, one being IBM. These companies donate computer time, training materials, and any needed equipment, such as terminals. The project has locations in both Stanford, Connecticut and White Plains, New York. It is a year-long program which provides on-the-job computer programming education and other related information processing skills. The program combines classroom lectures with work such as writing reports and programs and serving on various committees [11].

The use of flex-time, job sharing, or part-time hours can be inexpensive ways to handle the question of "reasonable accommodation." According to a recent study, 45 percent of 447 daily newspapers in the country had recently or were in the process of altering their newspaper plants. This involved either access into various rooms or installing elevators. The cost ranged from $\$ 200$ to $\$ 15,000$ [18]. There are various technological aids available that help the handicapped increase their job opportunities; however, some of the aids can be expensive.

\section{Conclusions}

Congress is poised to pass another major civil rights act; this one aimed at 43 million Americans - the disabled. The Americans With Disabilities Act will have a major impact on the employment practices of American business. Viewed correctly this legislation can help businesses solve one of their major problems of the 1990s. With the decreasing labor pool of applicants, companies can increase their recruitment pool by including the handicapped-a source which is increasing in size. Several major corporations, IBM, Dupont, Union Carbide, have done this successfully and there is no reason that small businesses couldn't be just as successful. A major reason for the success of these companies is the commitment by the company's top management to the accommodation of the handicapped worker. Managers have been encouraged to study the job design and work environment and look for changes that will benefit these workers. Successful accommodation experiences are shared within the firm as well as with other companies. Training is provided to help company personnel change their beliefs about the capabilities of the handicapped-common myths are examined and tested. The way has been paved for increased utilization of a productive segment of the labor force. 


\section{References}

1. "ADA Update." Worklife. (Fall, 1989), pp. 21-25.

2. Allard, H. S. and Jaboe, G. "Removing Barriers in the Electronic Workplace," Personnel Administrator (February, 1986), pp. 65-75.

3. Bauer, D. and J. Green. "The Disabled Battle Job Prospects." Management Review (April, 1988), pp. 59-61.

4. Berlinski, P. "A Hidden Resource." Restaurant Business (July 1, 1987), p. 16.

5. Bragman, R. S., and J. Couch Sole. "Free Services Help Employer Accommodate Disabled Workers." Training and Development Journal (October, 1984), p. 10.

6. Brown, A. "Tapping an Untapped Resource." Personnel Administration (August, 1982), pp. $65-75$.

7. Carrell, M. R. and W. T. Heavin Jr. "The 'Hand-Capable' Employee: An Untapped Resource." Personnel (August, 1987), pp. 40-45.

8. Combs, I. H. and C. P. Omvig. "Accommodations of Disabled People into Employment: Perceptions of Employers." Journal of Rehabilitation (April/May/June 1986), pp. 37-41.

9. Feldman, D. "Employing Physically and Mentally Impai ed Employees." Personnel (January, 1988), pp. 14-15.

10. Galvin, D. E. and R. T. Roessler. "Employee Support Services: A Sound Investment." Personnel (July, 1986), pp. 54-58.

11. "Helping the Disabled Join the Business World." The Office (May, 1986), p. 52.

12. Jarvis, S. S. "For Employers of Handicapped Workers" Obligations and Ideas." Personnel (July, 1985), p. 42.

13. Kraus, L. E. "Disability and Work" Worldlife, Vol. 2, No. 3 (Fall, 1989), pp. 37-39.

14. Larson, D. A. "What Disabilities are Protected Under the Rehabilitation Act of 1973?" Labor Law Journal (November, 1986), pp. 752-766.

15. McClure, F. G. and R. K. Robinson. "AIDS and the Law." Personnel Administrator (April, 1988), pp. 118-121.

16. “Ordinary People." American Demographics (1987), p. 17. 
17. Peters, J. "Alternative Labor Pool." Restaurant Business (September 1, 1987), pp. 183187.

18. Popovich, M. and S. C. Willis. "Study: Newspapers Want to Hire More Handicapped Workers." Editor and Publisher (May 3, 1986), p. 60.

19. "Report of the Disability Advisory Council: Executive Summary." Social Security Bulletin, Vol. 51 (1988), pp. 13-17.

20. Schapire, J. and F. Berger. "Responsibilites and Benefits in Hiring the Handicapped." The Cornell H.R.A. Quarterly (February, 1984), pp. 59-67.

21. Solomon, J. "Firms Address Workers' Cultural Variety." Wall Street Joumal (February 10, 1989), p. B-1.

22. Stace, S. "Vocational Rehabilitation for Women with Disabilities." International Labor Review, Vol. 126 (1987), pp. 301-314.

23. Stackel, L. "Accommodating the Disabled in the Work Place." Employment Relation Today (Summer, 1986), pp. 177-181.

24. Strom, L. J. and G. R. Ferris. "Issues in Hiring the Handicapped: A Positive Outlook" Personnel Administrator (August, 1982), pp. 75-81.

25. U. S. Commissions on Civil Rights: Civil Rights Issues of Handicapped Americans: Public Policy Implications. Washington, D.C. (1980).

26. Wagel, S. H. "Project Ace: New Opportunities for People with Disabilities." Personnel January, 1988), pp. 9-13.

27. Williams, J. M. "Talking Computers Help Blind Programmers." ABA Banking Journal (June, 1983), pp. 92-3.

28. Williams, J. M. "TSI's Jim Bliss on Computers and Disabled Workers." Personnel Administrator (August, 1986), pp. 61-62.

29. Williams, J. M. "Technology and the Disabled." Personnel Administrator (July, 1988), pp. 81-83.

30. Young, J., Rosati, R., and D. Vandergoot. "Initiating a Marketing Strategy by Assessing Employer Needs for Rehabilitation Services." Iournal of Rehabilitation (April/May/ June, 1986), pp. 37-41. 